\title{
Decreased matrix degradation in diabetic nephropathy: effects of ACE inhibition on the expression and activities of matrix metalloproteinases
}

\author{
S. V.McLennan ${ }^{3}$, D.J.Kelly ${ }^{1}$, A.J.Cox ${ }^{1}$, Z.Cao ${ }^{4}$, J. G. Lyons ${ }^{2}$, D.K. Yue ${ }^{3}$, R. E. Gilbert ${ }^{1}$ \\ ${ }^{1}$ University of Melbourne Department of Medicine, St. Vincent's Hospital, Fitzroy, Victoria, Australia \\ ${ }^{2}$ Kanematsu Institute, RPA Hospital, Sydney, New South Wales, Australia \\ ${ }^{3}$ Department of Medicine, University of Sydney, Sydney, New South Wales, Australia \\ ${ }^{4}$ Department of Medicine, University of Melbourne, Austin and Repatriation Medical Centre (Repat Campus), Victoria, \\ Australia
}

\section{Abstract}

Aims/hypothesis. Extracellular matrix accumulation is thought to be involved in the pathogenesis of diabetic nephropathy. Increased matrix synthesis has been well documented but the effects of diabetes on degradative pathways, particularly in the in vivo setting, have not been fully explored. Furthermore, the effect of renoprotective therapies on matrix accumulation through these pathways has not been examined. We investigated the degradative pathway of type IV collagen and the effects of ACE inhibition in experimental diabetic nephropathy.

Methods. Diabetes was induced in 16 rats by administrating streptozocin; 8 of the diabetic rats were allocated at random to receive the ACE inhibitor perindopril $(2 \mathrm{mg} / \mathrm{l})$ in their drinking water and 8 age and weight matched rats served as controls. Gene expression of matrix metalloproteinase $(M M P)$ and tissue inhibitor of metalloproteinase (TIMP) was measured by RT-PCR and type IV collagen content by immunohistochemistry. MMP activities were determined by degradation of a radiolabelled substrate and by zymography.

Results. Six months of diabetes was associated with a decrease in mRNA and enzymatic activity of MMP-
$9(21 \%$ and $51 \%$ respectively, $p<0.05$ vs control) and a $51 \%$ increase in TIMP- 1 mRNA ( $p<0.05$ vs control). By contrast, MMP-2 mRNA was increased but its activity decreased $(43 \%$ and $43 \%$ respectively, $p<0.05$ vs control). Total degradative capacity of kidney tissue from diabetic rats was also lower (Control: $48 \pm 7 \%$, Diabetic: $33 \pm 6 \%, p<0.05$ ). Activation of latent MMPs with amino-phenylmercuric acetate increased matrix degradation by two-fold. However the relative decrease associated with experimental diabetes still remained. All diabetes-associated changes in MMP and TIMP mRNA and activities were attenuated by perindopril treatment in association with reduced type IV collagen accumulation. Conclusions/interpretation. These results indicate that the impairment of matrix degradation contributes to matrix accumulation in diabetic nephropathy and that the beneficial effects of ACE inhibition could in part be mediated by modulation of changes in matrix degradative pathways. [Diabetologia (2002) 45: 268-275]

Keywords Matrix metalloproteinase, diabetic nephropathy, angiotensin converting enzyme, extracellular matrix, type IV collagen.
Received: 13 June 2001 and in revised form: 14 September 2001

Corresponding author: S. V. McLennan, Department of Medicine, University of Sydney, Sydney, New South Wales, Australia, 2006, e-mail: sue@med.usyd.edu.au

Abbreviations: ACE, Angiotensin converting enzyme; AER, albumin excretion rate; APMA, aminophenylmercuric acetate; DPM, disintegrations per minute; ECM, extracellular matrix; MMP, matrix metalloproteinase; TIMP, tissue inhibitor of metalloproteinase; SDS, sodium dodecyl sulphate
The accumulation of extracellular matrix (ECM) within the kidney is an ultrastructural hallmark of diabetic nephropathy and is directly linked to a decline in renal function [1]. This increase of ECM can result from either increased synthesis and decreased degradative activity or both. Several studies have shown that high glucose concentration increases synthesis of ECM proteins in both mesangial and tubular epithelial cells [2]. However, more recently it has also 
been recognised that high glucose concentration can also affect the activities of the matrix metalloproteinases (MMPs), a large group of metal ion-dependent enzymes responsible for matrix degradation. Studies from our own laboratory and by others have shown that the high glucose concentration in diabetes can alter the activities of these enzymes in mesangial cells and in isolated glomeruli [3-5].

While initially believed to have a solely haemodynamic basis, the renoprotective effects of angiotensin converting enzyme (ACE) inhibition could also include reduction in the non-haemodynamic effects of angiotensin II [6]. In vivo studies have shown that ACE inhibition attenuates the increased synthesis of ECM in diabetes [7, 8]. However, the effects of ACE therapy on matrix degradative pathways have not been examined in detail in the in vivo setting. Most investigations in both human and experimental diabetes have focussed on the changes in ECM deposition within the glomerulus. But a number of studies have also shown a concomitant accumulation of the matrix within the tubulointerstitium $[1,9,10]$. Indeed, the deposition of ECM within the tubulointerstitium also correlates closely with the progression of renal disease in diabetes. This study examined the effects of ACE inhibition on the degradative pathways of the major renal ECM protein, type IV collagen [11], in the whole kidney of animals with experimental diabetes.

\section{Materials and methods}

Animals. Diabetes was induced in 16 Sprague Dawley rats by the intravenous injection of streptozocin $(50 \mathrm{mg} / \mathrm{kg})$. A further eight age-matched rats, injected with citrate buffer, were used as non-diabetic controls. All diabetic rats received $4 \mathrm{U} /$ day long-acting insulin (Ultratard, Novo-Nordisk, Bagsvegaard, Sweden) to maintain body weight and to prevent ketoacidosis. To determine the effect of ACE inhibition, diabetic rats were also allocated at random to receive the ACE inhibitor perindopril ( $n=8$, Servier, Neuilly, France) in their drinking water $(2 \mathrm{mg} / \mathrm{l})$. This was equivalent to a mean dose of $(2 \mathrm{mg} / \mathrm{kg} /$ day $)$ for the duration of the study. Both courses of treatment commenced 1 week after the induction of diabetes.

Seven days before the rats were killed, they were housed in metabolic cages for $24 \mathrm{~h}$ to obtain urine for the measurement of albumin by radioimmunoassay [12]. At 24 weeks of diabetes, rats were anaesthetised with pentobarbital and the kidneys obtained for RNA extraction and immunohistochemistry as previously described [13]. Blood obtained at death was collected in lithium heparin tubes, spun, separated and stored at $-20^{\circ} \mathrm{C}$. The $\mathrm{HbA}_{1 \mathrm{c}}$ was determined by high performance liquid chromatography. All aspects of the experiment were approved by the Animal Ethics Committee of the Austin and Repatriation Medical Centre, Melbourne, Australia.

MMP and TIMP gene expression. Kidney tissue was homogenised (Ultra-Turrax, Janke and Kunkel, Stafen, Germany) and total RNA isolated using the guanidinium isothiocyanate-phenol-chloroform extraction method [14]. One microgram aliquots of kidney tissue from each rat were reverse transcribed
Table 1. Oligonucleotide primer sequences and expected PCR product sizes for each of the MMPs and TIMPs

\begin{tabular}{lll}
\hline & Oligo nucleotide sequence & $\begin{array}{l}\text { Product } \\
\text { length }\end{array}$ \\
\hline MMP-2 & $\begin{array}{l}\text { sense 5' cca cat tct ggc ctg agc tcc c } \\
\text { anti sense 5' gat ttg atg ctt cca aac ttc ac }\end{array}$ & 436 bp \\
MMP-9 & $\begin{array}{l}\text { sense 5' cgc caa cta tga cca gga ta } \\
\text { anti sense 5' gtt gcc ccc agt tac agt }\end{array}$ & $71 \mathrm{bp}$ \\
TIMP-1 & $\begin{array}{l}\text { sense 5' aat ttg cac atc act gcc } \\
\text { anti sense 5' gtg atc gct ctg gta gc } \\
\text { sense 5' cag gcg ttt tgc aat gc } \\
\text { anti sense 5' gat ctc ata ttg aat cct c }\end{array}$ & $213 \mathrm{bp}$ \\
Beta-actin & $\begin{array}{l}\text { sense 5' tac aac ctc ctt gca gct cc } \\
\text { anti sense 5' gga tct tca tga ggt agt ctg tc }\end{array}$ & 114 bp \\
\hline
\end{tabular}

into cDNA using oligo dT (10pmol, Gibco-BRL, Sydney Australia) and Superscript II RNase $\mathrm{H}^{-}$(Gibco-BRL) according to the manufacturers instructions. The gelatinases MMP-2 and MMP-9, and the tissue inhibitors of MMPs, TIMP-1 and TIMP-2 were amplified using $2 \mathrm{U}$ Taq polymerase (P. E. Biosystems, Forster City, Calif., USA) and 20 pmol of each forward and reverse primer as shown in Table 1 . The cycling parameters were denaturation $\left(94^{\circ} \mathrm{C}, 15 \mathrm{~s}\right)$, annealing $\left(54^{\circ} \mathrm{C}, 30 \mathrm{~s}\right)$ and extension $\left(72^{\circ} \mathrm{C}, 30 \mathrm{~s}\right)$ [15]. The number of cycles $(25-30)$ for each $M M P$ or $T I M P$ was selected to be well within the linear amplification range. Gene expression of beta actin was also measured in each sample and used as control for loading and reverse transcription efficiency. Negative control RT-PCR reactions was done by omitting either the reverse transcriptase enzyme or the RNA from the reaction mixture. All negative controls failed to produce PCR amplicons (data not shown). The resulting PCR products were electrophoretically fractionated on polyacrylamide gels $(12.5 \%)$ and visualised by staining with SYBR Green II (Molecular Probes, Eugene, OR, USA). Gels were then photographed and the images directly digitised using GrabIt software (UVP, Cambridge, UK) the intensity of the bands was determined using the Phoretix Image Analysis Programme (Phoretix International, Newcastle Upon Tyne, UK). Results were expressed as a ratio of band intensity corrected for abundance of the housekeeping gene, beta-actin.

Gelatinase activity. Tissue samples $(100 \mathrm{mg})$ were homogenised and the protein concentration determined (Biorad DC, Sigma, Australia). The protein concentration in each sample was standardised and the presence of gelatinase activity determined by zymography as previously described [16] and according to the methodology of Zucker et al in which protein samples are assayed within the linear part of the calibration curve [17]. In brief, kidney samples ( $20 \mu \mathrm{g}$ protein $)$ from each experimental animal were mixed with sample buffer and loaded onto a $10 \%$ SDS polyacrylamide gel containing $1 \mathrm{mg} / \mathrm{ml}$ gelatin and electrophoresed under non-reducing conditions $(100 \mathrm{~mA} / \mathrm{gel})$. After electrophoresis the gels were washed in $50 \mathrm{mmol} / \mathrm{l}$ TRIS buffer, $\mathrm{pH} 7.6$ containing $2.5 \%$ Triton X-100 to displace SDS. The gels were incubated for a further $24 \mathrm{~h}$ in $50 \mathrm{mmol} / 1$ TRIS buffer containing $5 \mathrm{mmol} / 1 \mathrm{CaCl}_{2} \mathrm{pH} 7.6$ and gelatin degrading enzymes were identified by staining with Coomassie Blue and destaining in methanol/acetic acid/H2O. Using this method, gelatinases appear as clear bands on a blue background and can be identified by their molecular weight. Gels were photographed and directly digitised using GrabIt software (UVP, Cambridge, UK) band size was determined using the Phoretix Image Analysis Program (Phoretix International, Newcastle -Upon-Tyne, UK). 
Ability of kidney tissue to degrade matrix and preparation of labelled matrix substrate. Labelled mesangium matrix substrate was prepared for use in the degradation studies as previously described [3]. Briefly, mesangial cells were plated in 12-well plates and cultured in RPMI (Gibco-BRL, Sydney, Australia) medium containing $10 \%$ FCS. At approximately $60 \%$ confluence the medium was changed to RPMI containing $10 \%$ FCS and $\left[{ }^{35} \mathrm{~S}\right]$ methionine (Tran ${ }^{35} \mathrm{~S}$ label; ICN, Irvine, Calif., USA). At confluence the media was removed and the mesangial cells washed with phosphate buffered saline (PBS) and separated from their matrix with $0.25 \mathrm{~N} \mathrm{NH}_{4} \mathrm{OH}$ at $37^{\circ} \mathrm{C}$ for $30 \mathrm{~min}$. The labelled matrices were then washed with distilled water, fixed with $70 \%$ ethanol and exposed to UV light for $10 \mathrm{~min}$. Just before the degradation studies, the matrices were again washed with PBS.

Degradation studies. Labelled matrices prepared as described above were used to study the effect of ACE inhibition on the activities of proteolytic enzymes in the kidney tissue. For these studies, duplicates of samples from experimental animal containing $20 \mathrm{mg}$ protein were resuspended in $500 \mu \mathrm{l} \mathrm{of} 50 \mathrm{mmol} /$ 1 TRIS buffer containing $5 \mathrm{mmol} / \mathrm{C} \mathrm{CaCl}_{2}$ and incubated with the labelled matrix substrate for $24 \mathrm{~h}$ at $37^{\circ} \mathrm{C}$. The degradative ability of each sample was also determined after inhibition with EDTA or activation of enzymes with aminophenylmercuric acetate (APMA). Activation was achieved by incubation of the kidney tissue with $1 \mathrm{mmol} / \mathrm{l}$ APMA for $1 \mathrm{~h}$ at $37^{\circ} \mathrm{C}$ before incubation with the labelled matrix substrate. Degradation was then assessed by counting the release of $\left[{ }^{35} \mathrm{~S}\right]$ methionine from the substrate in a liquid scintillation counter (2500TR, Packard Instruments City, Conn., USA) and expressed as disintegrations per minute (DPM).

The non-specific release of radioactivity was determined by incubation of the matrices in the presence of $50 \mathrm{mmol} / 1 \mathrm{TRIS}$ buffer (containing $5 \mathrm{mmol} / 1 \mathrm{CaCl}_{2}$ ) and $0.1 \%$ albumin and was found to be $5.4 \pm 2.3 \%$ of the total count. Control experiments, co-incubating the kidney tissue with EDTA or 1,10 phenanthroline $(10 \mathrm{mmol} / \mathrm{l}$ final concentration $)$ before measuring the degradative activity, inhibited the ability of the tissue to degrade the matrix by $75.6 \pm 5.6 \%$. This decrease indicated that most of the degradation was due to the actions of MMPs.

Type IV collagen accumulation. Type IV collagen accumulation was assessed immunohistochemically as previously described [11]. Briefly, sections $(4 \mu \mathrm{m})$ of the formalin fixed and paraffin embedded kidney were placed onto slides, deparaffinised and rehydrated. To retrieve antigenicity from formalin fixation, sections were incubated for $10 \mathrm{~min}$ in $10 \mathrm{mmol} / \mathrm{l}$ sodium citrate buffer using a microwave oven. Endogenous peroxidase activity was blocked by further pretreatment with $1 \% \mathrm{H}_{2} \mathrm{O}_{2} /$ methanol followed by incubation in protein blocking agent (Lipshaw-Immunon, Pittsburgh, Penn., USA) for $20 \mathrm{~min}$ at room temperature. The sections were then incubated with polyclonal goat anti-bovine/anti human type IV collagen antibody (Southern Biotechnology, Birmingham, Alabama, USA) overnight at $4{ }^{\circ} \mathrm{C}$. The following day the sections were thoroughly washed in PBS and incubated with rabbit anti-goat (1:200) biotinylated IgG (DAKO, Carpinteria Calif., USA) followed by avidin-biotin peroxidase complex (Vector, Burlingame, Calif., USA). Localisation of the peroxidase conjugates was achieved using diaminobenizidine tetrahydrochloride as a chromagen. Sections incubated in the absence of either primary antibody or in the presence of normal rabbit IgG served as negative controls.

The amount of Type IV collagen accumulation was assessed by examining immunostained sections using the com- puter-assisted image analysis method [18-20]. In brief, the colour range for positive brown staining on immunoperoxidase labelled sections was selected and image analysis done using a chromogen-sensitive technique [18]. Images from three non-overlapping, randomly selected fields of each experimental animal were examined using light microscopy (Olympus BX-50, Olympus Optical, Tokyo, Japan) and digitised using a high-resolution camera (Fujix HC-2000, Fujifilm, Tokyo, Japan). The proportional area occupied by immunoreactive type IV collagen was then calculated. All images were obtained using a $20 \times$ objective lens. Digitised images were then captured on a Power Macintosh G3 computer (Apple Computer, Cupertino, Calif., USA) and evaluated using analytical software (AIS, Analytical Imaging Software, City Ontario, Canada).

Statistical analysis. Because of a positively skewed distribution, AER was logarithmically transformed before statistical analysis and expressed as the geometric mean $\cdot 1 \div$ tolerance factor. Other results are expressed as means \pm SEM unless stated otherwise. Data were compared using analysis of variance (ANOVA) followed by post hoc comparison using Duncan's Multiple Range test. Analyses were done using the Statview SE + Graphics package (Abacus Concepts, Calabasas, Calif., USA) on an Apple Macintosh G3 (Apple Computer). A $p$ value $<0.05$ was considered statistically significant.

\section{Results}

Clinical parameters. All rats that received streptozocin became diabetic (blood glucose $>15 \mathrm{mmol} / \mathrm{l}$ ) and treatment of diabetic rats with perindopril had no effect on blood glucose concentrations or $\mathrm{HbA}_{1 \mathrm{c}}$ when compared with untreated diabetic animals (Table 2). Diabetes was associated with an increase $(p<0.01)$ in kidney weight and loss in body weight. These changes were also not affected by perindopril treatment. The AERs and systolic BP of the perindopril treated rats were similar to those observed in the control animals and significantly less than those seen in diabetic animals (Table 2).

Gene expression of MMPs and TIMPs. Gene expression of $M M P-2$ was increased while $M M P-9$ mRNA was decreased in kidney tissue from diabetic animals when compared with non-diabetic controls (Fig. 1A and $1 \mathrm{~B}$, respectively). TIMP-1 gene expression was also increased in diabetic rat kidneys (Fig. 2). These changes in expression of $M M P-2, M M P-9$ and TIMP-1 were all prevented by treatment with perindopril. TIMP-2 gene expression did not differ among any of the experimental groups (data not shown).

Gelatinase activity. Gelatin zymography (Fig.3A) revealed two major bands of enzymatic activity in kidney extracts, corresponding to MMP-9 (92 kDa) and MMP-2 (72 kDa). Diabetes was associated with a reduction in both MMP-2 and MMP-9, a decrease prevented by treatment of diabetic animals with perindopril (Fig. 3B and 3C). 
A
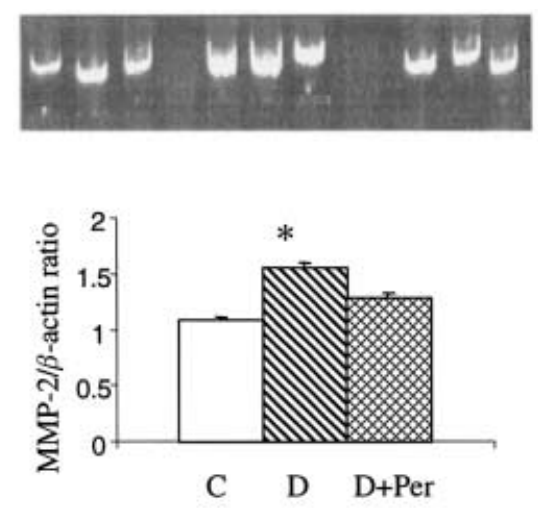

Fig.1(A, B). RT-PCR analysis of kidney $M M P-2$ (A) and $M M P-9(\mathbf{B})$ mRNA. Representative SYBR green stained gel obtained from control (C) diabetic (D) and perindopril-treated diabetic rats $(\mathrm{D}+\mathrm{Per})$ are shown. The mean values $n=8$ for each group ( $\pm \mathrm{SEM}$ ) for $M M P-2$ or $M M P-9$ in relation to beta-actin are also shown. ${ }^{*} p<0.05$ significantly different from control

Matrix degradative activity. Total matrix degradative activity as assessed by release of $\left[{ }^{35} \mathrm{~S}\right]$ methionine from the radiolabelled matrix substrate was reduced in kidney homogenates from diabetic rats compared with control rats. This decrease in degradative activity was normalised by perindopril treatment (Fig. 4A). Addition of APMA to the kidney homogenates increased the degradative activity two- to threefold in all samples irrespective of treatment such that matrix degradation remained impaired in APMA-treated tissue samples from diabetic rats (Fig. 4B).

Type IV collagen. Immunohistochemistry showed an increase in Type IV collagen in the kidney sections obtained from diabetic rats compared with control and perindopril-treated diabetic rats (Table 3 ). Increased immunostainable type IV collagen was present both in glomeruli (Fig.5) and in the tubulointerstitium (Fig. 6) of diabetic rat kidneys.
B
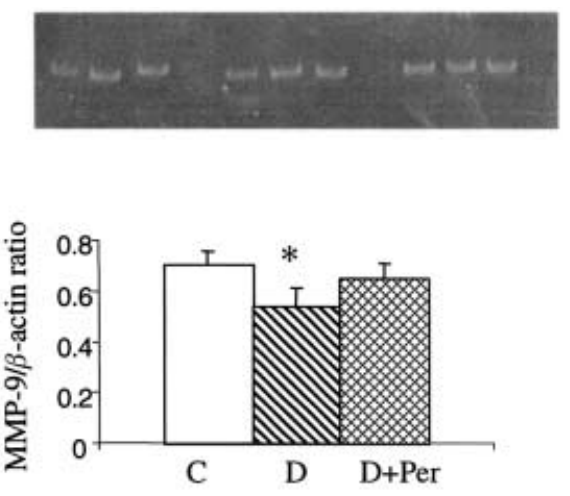

\section{Discussion}

This study uncovers several findings in relation to the pathogenesis of experimental diabetes. Firstly, impaired degradation contributes to ECM accumulation in the diabetic kidney. Secondly, the beneficial effects of ACE inhibition on matrix accumulation could, in part, be mediated by its effects on the activities of enzymes involved in matrix degradation. Thirdly, in the diabetic context, changes in enzyme activity cannot be inferred from alterations in gene expression alone.

The pathological hallmark of progressive renal disease is the accumulation of ECM in the glomerulus and tubulointerstitium with changes at both sites correlating closely with declining renal function (reviewed in [21]). This accumulation results from an imbalance between synthetic and degradative pathways. While the mechanisms mediating increased synthesis have been the focus of considerable attention, changes in the matrix degradative pathway in progressive kidney disease have not been explored in detail. Matrix degradation is largely mediated by the MMPs, a family of some 26 zinc-dependent enzymes that are active at neutral $\mathrm{pH}$ and secreted extracellularly as inactive zymogens [22]. Their activities are tightly regulated at multiple levels; by modulation in transcription, by changes in the rate of posttranslational modification via enzyme-dependent cleavage of pro-MMPs and by alterations in the concentration of specific inhibitors, the TIMPs.

Table 2. Rat characteristics at end of study

\begin{tabular}{|c|c|c|c|}
\hline & Control rats & Diabetic rats & Diabetic + perindopril \\
\hline$n$ & 8 & 8 & 8 \\
\hline Body weight (g) & $507 \pm 12$ & $360 \pm 25^{\mathrm{c}}$ & $384 \pm 17^{\mathrm{c}}$ \\
\hline Kidney weight (g) & $1.42 \pm 0.04$ & $1.96 \pm 0.15^{\mathrm{c}}$ & $2.02 \pm 0.12^{\mathrm{c}}$ \\
\hline Blood glucose concentrations (mmol/l) & $5.0 \pm 2.3$ & $24.2 \pm 2.7^{\mathrm{c}}$ & $22.0 \pm 1.2^{\mathrm{c}}$ \\
\hline $\mathrm{HbA}_{1 \mathrm{c}}(\%)$ & $4.4 \pm 0.5$ & $11.7 \pm 0.6^{\mathrm{c}}$ & $10.9 \pm 0.7^{\mathrm{c}}$ \\
\hline $\operatorname{AER}(\mathrm{mg} /$ day $)$ & $0.60 \mathrm{x} / \div 1.4$ & $4.0 \times / \div 1.4^{\mathrm{c}}$ & $0.40 \mathrm{x} / \div 1.71^{\mathrm{b}}$ \\
\hline
\end{tabular}

Data expressed as means \pm SEM except for AER which is expressed as geometric mean $\cdot / \div$ tolerance factor

\footnotetext{
${ }^{\mathrm{a}} p<0.05$ versus control

${ }^{\mathrm{b}} p<0.05$ versus diabetic

${ }^{\mathrm{c}} p<0.01$ versus control
} 

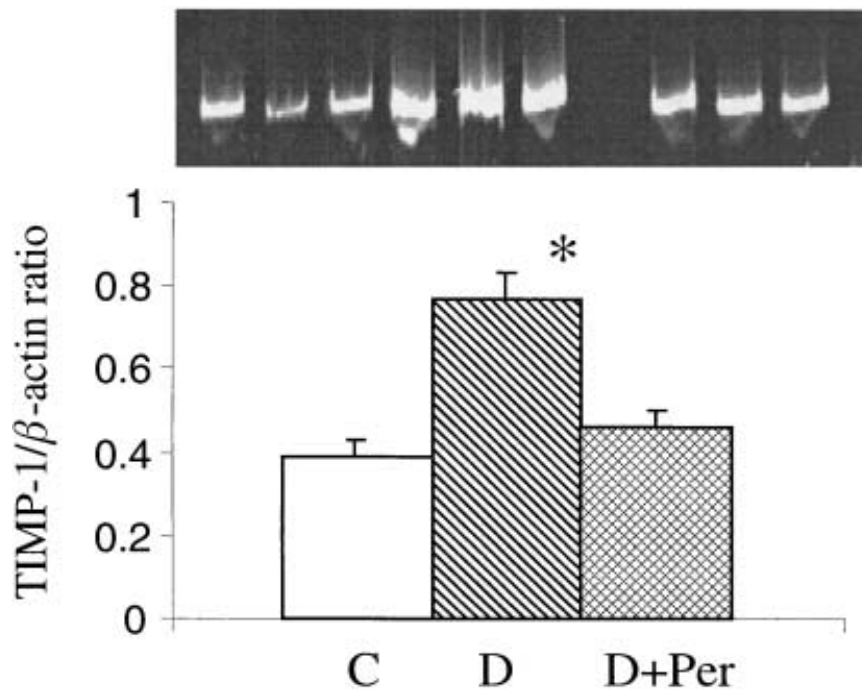

Fig. 2. RT-PCR analysis of kidney TIMP-1 gene expression. Representative SYBR green stained gel obtained from control (C) diabetic (D) and perindopril-treated diabetic rats $(\mathrm{D}+$ Per) are shown. The mean values $n=8$ per group ( \pm SEM) for TIMP-1 mRNA in relation to beta actin are also shown. ${ }^{*} p<0.05$ significantly different from control

In this study, degradation of type IV collagen, the major ECM component of both the glomerulus and tubulointerstitium [11] increased at both sites in experimental [7, 8] and human diabetes [23]. Gene expression of the type IV collagenases, $M M P-2$ and $M M P-9$ were affected in different ways by the diabetic state, with increased gene expression of $M M P-2$ and reduced expression of $M M P-9$. The differential regulation of the components of the matrix degradative pathways has been previously documented [24, 25] and could be influenced by a range of factors which are altered in the diabetic milieu [26]. In particular, transforming growth factor- $\beta$ (TGF- $\beta$ ), a prosclerotic growth factor, that has been consistently implicated in the ECM accumulation of diabetic nephropathy [27] acts by inhibiting matrix degradation as well as by stimulating its synthesis [28]. Indeed, our findings that $M M P-2$ and TIMP-1 gene expression were increased, while $M M P-9$ mRNA was decreased, were consistent with the described actions of TGF- $\beta[25$, 26]. Furthermore, perindopril altered the changes in $M M P-2$ and TIMP-1 consistent with a previously reported diminution in the overexpression of TGF- $\beta$ with ACE inhibition [7]. Previous in vivo studies have examined only the gene expression $[4,29,30]$. Furthermore, these studies have focussed on MMP-1 and MMP-3, enzymes which degrade type I collagen and matrix glycoproteins and not collagen IV, the major ECM component of both the glomerulus and tubulointerstitium in the diabetic kidney [7,29]. This study has not only examined gene expression of the major components of the type IV collagen degradative path-
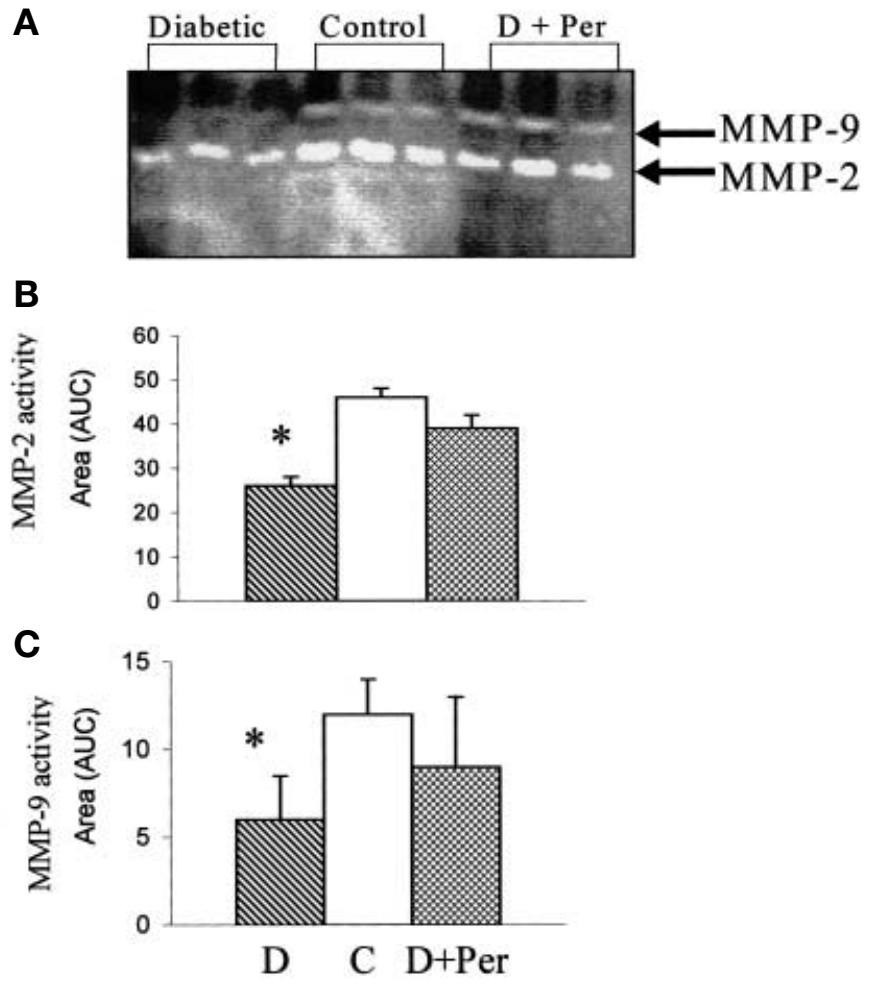

Fig. 3. Zymographic analysis of kidney MMP-2 and MMP-9 activity. A Representative zymogram of results obtained from diabetic (D), control (C) and perindopril-treated diabetic rats $(\mathrm{D}+$ Per $)$. B The mean values $n=8$ per group $( \pm$ SEM) of MMP-2 activity in the three groups. C The mean values ( \pm SEM) of MMP-9 activity in the three groups. ${ }^{*} p<0.05$ significantly different from control

Table 3. Type IV collagen content as assessed by image analysis

\begin{tabular}{llll}
\hline & $\begin{array}{l}\text { Control } \\
\text { rats }\end{array}$ & $\begin{array}{l}\text { Diabetic } \\
\text { rats }\end{array}$ & $\begin{array}{l}\text { Diabetic }+ \\
\text { perindopril }\end{array}$ \\
\hline $\begin{array}{l}\text { Type IV collagen } \\
\text { \% area })\end{array}$ & 8 & 8 & 8 \\
\hline
\end{tabular}

Data are expressed as proportional area occupied by immunostainable type IV collagen

${ }^{\mathrm{a}} p<0.01$ vs control

${ }^{\mathrm{b}} p<0.01$ vs diabetic

way, but has also assessed the activities of these enzymes. In this study, despite the increase in $M M P-2$ mRNA, enzyme activity of both MMP-2 and MMP-9 as assessed by zymogram was impaired in tissue from diabetic rat kidneys. This decrease in activity by zymography is most likely to be due to a decrease in enzyme mass and cannot be explained by the overexpression of TIMP-1 as the high SDS concentration separates TIMPs from MMPs during zymography.

In addition to the specific changes in the type IV collagen degradative pathway, we also noted a net decrease in the ability of kidney tissue from diabetic rats 


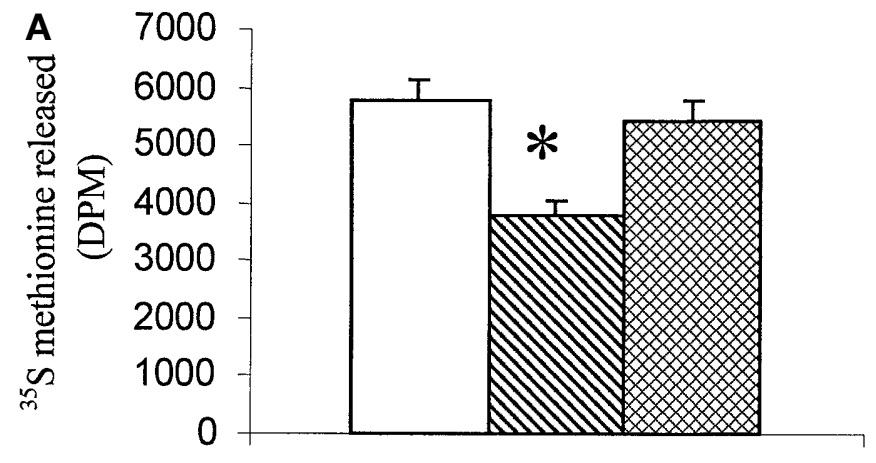

B

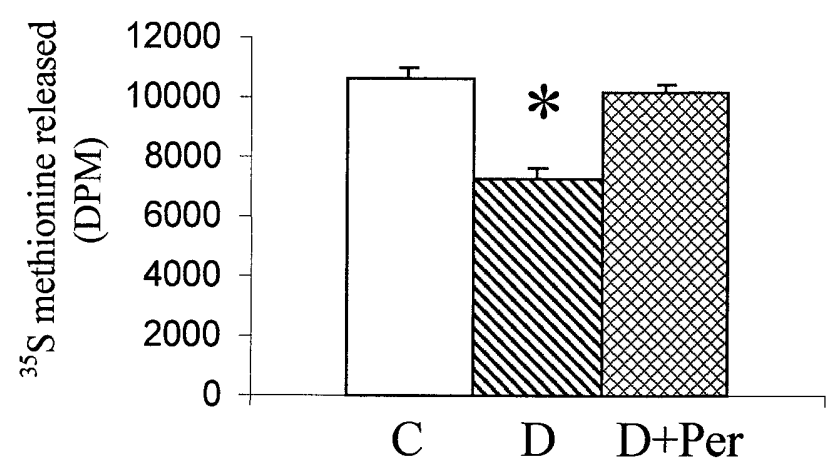

Fig. 4(A, B). Degradation of a labelled matrix substrate by kidney tissue from control (C) diabetic (D) and perindopriltreated diabetic rats $(\mathrm{D}+$ Per) either before $(\mathbf{A})$ or after $(\mathbf{B})$ activation of matrix metalloproteinases with APMA. $* p<0.05$ significantly different from control

to degrade a radiolabelled matrix substrate. The presence of MMPs in the kidney tissue was confirmed by the inhibition of the majority of their activity with EDTA or 1:10 phenanthroline [16]. Furthermore, when non-proteolytic activation of all MMPs was induced by the addition of the organomercurial, APMA, to the tissue sample, there was a two-fold increase in matrix degrading capacity of kidney tissue. However, APMA treatment did not abolish the difference between kidney tissue from diabetic and control rats. These findings indicate that in addition to changes in TIMPs, diabetes was associated with an overall decrease in the total MMP mass.

Several studies in both humans [31-33] and experimental rats $[34,35]$ have shown a renoprotective ef-

Fig.5(A-C). Representative photomicrographs of glomeruli from control (A), diabetic (B) and perindopril-treated diabetic rats $(\mathbf{C})$ immunostained with antibody to type IV collagen. Increased immunostainable type IV collagen (brown) is present in the glomeruli of diabetic rat kidneys compared with controls and perindopril treated diabetic animals. Magnification $\times 320$
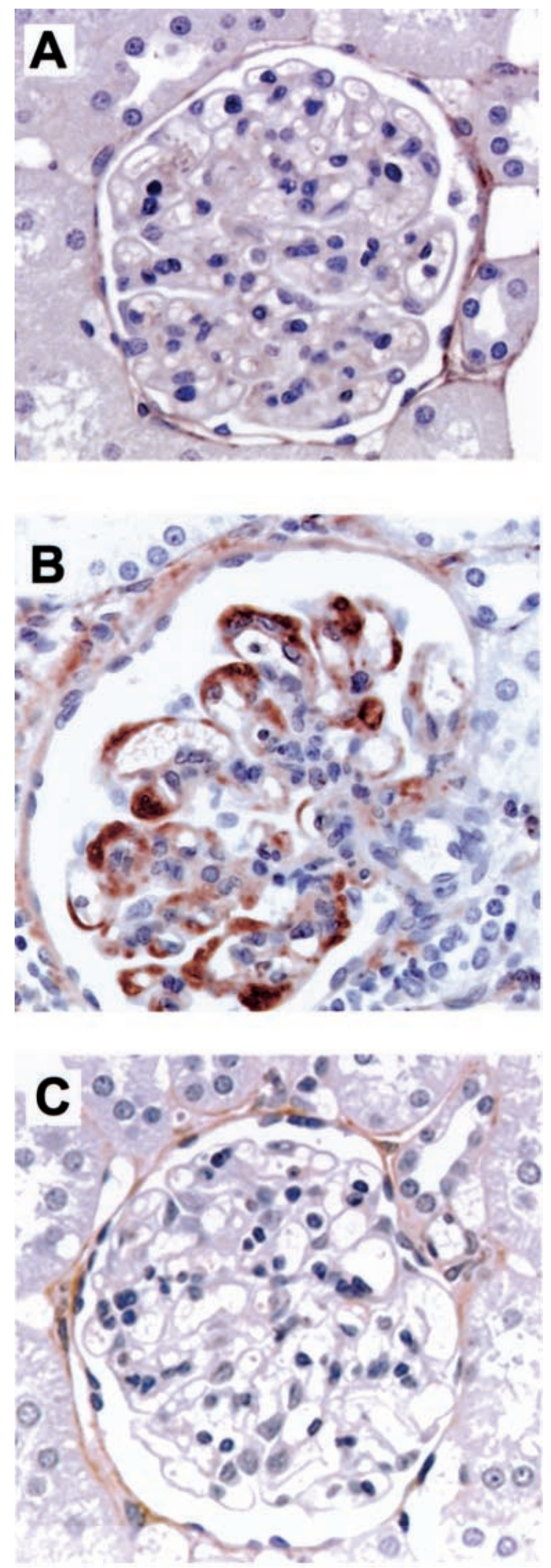

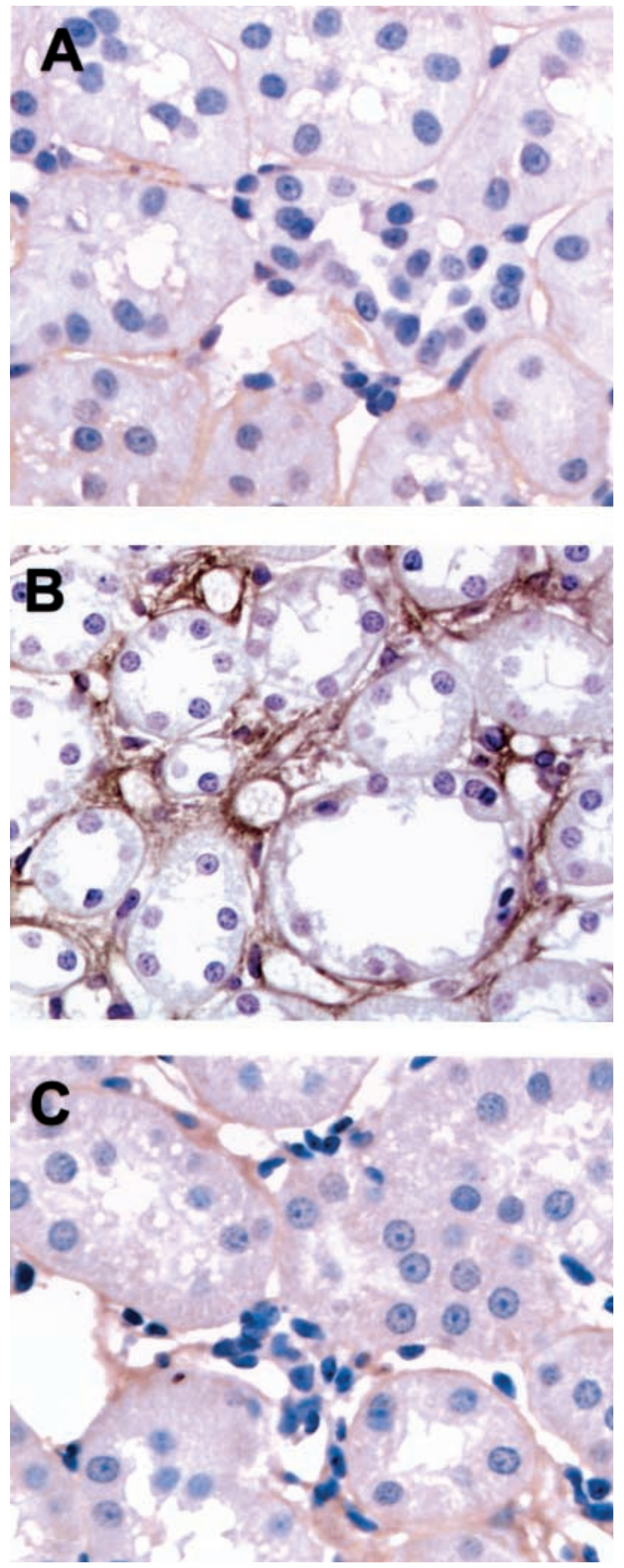

Fig.6(A-C). Representative photomicrographs of tubules form control (A), diabetic (B) and perindopril-treated diabetic rats $(\mathbf{C})$ immunostained with antibody to type IV collagen. Magnification $\times 320$ fect of ACE inhibition in diabetes. In vitro, angiotensin II, the effector molecule of the renin-angiotensin system, stimulates TGF- $\beta$ expression in mesangial cells [36], proximal tubular epithelial cells [37] and renal interstitial fibroblasts [38]. Furthermore, in experimental diabetes, blockade of the renin-angiotensin system leads not only to a reduction in glomerular ultrastructural damage [39] and reduced ECM gene transcription in the glomerulus [8], but also to a reduction in both TGF- $\beta$ and collagen accumulation in the tubulointerstitium [7]. Similar effects of ACE inhibition on ECM accumulation have also been recently reported in human diabetic nephropathy [40]. Whether these beneficial changes are due to modulation of degradative as well as synthetic pathways is not clear $[7,8]$. In contrast to our study, Nakamura et al did not demonstrate an effect of enalapril on $M M P$ or TIMP gene expression. The reason for differences are not clear but could reflect the MMPs examined and ACE inhibitor used. The findings of our study are, however, most consistent with the previously reported in vitro experiments in which exposure of cultured mesangial cells to high glucose decreased MMP-2 activity by an angiotensin II-dependent pathway [41]. Together with the results of this study, these findings indicate the important interactions between hyperglycaemia and the renin-angiotensin system in mediating ECM accumulation in diabetes by both impairing its degradation as well as increasing its synthesis. Preventing these effects could contribute to the beneficial effects of ACE inhibition on the structural as well as the functional abnormalities of diabetic nephropathy.

Acknowledgements. Dr Gilbert is the recipient of a Career Development Award and Dr. Kelly is the recipient of a postdoctoral fellowship, both from the Juvenile Diabetes Foundation International. S. McLennan and Dr Yue are supported by grants from the Diabetes Australia Research Trust and the Juvenile Diabetes Research Foundation.

\section{References}

1. Mauer SM (1994) Structural-functional correlations of diabetic nephropathy. Kidney Int 45: 612-622

2. Ziyadeh FN, Snipes ER, Watanabe M, Alvarez RJ, Goldfarb S, Haverty TP (1990) High glucose induces cell hypertrophy and stimulates collagen gene transcription in proximal tubule. Am J Physiol 259: F704-F714

3. McLennan SV, Fisher EJ, Yue DK, Turtle JR (1994) High glucose concentration causes a decrease in mesangium degradation. A factor in the pathogenesis of diabetic nephropathy. Diabetes 43: 1041-1045

4. Nakamura T, Fukui M, Ebihara I, Osada S, Tomino Y, Koide H (1994) Abnormal gene expression of matrix metalloproteinases and their inhibitor in glomeruli from diabetic rats. Ren Physiol Biochem 17: 316-325

5. Song RH, Singh AK, Leehey DJ (1999) Decreased glomerular proteinase activity in the streptozotocin diabetic rat. Am Nephrol 19: 441-446 
6. Border WA, Noble NA (1998) Evidence that TGF-beta should be a therapeutic target in diabetic nephropathy. Kidney Int 54: 1390-1391

7. Gilbert RE, Cox A, Wu LL et al. (1998) Expression of transforming growth factor-beta1 and type IV collagen in the renal tubulointerstitium in experimental diabetes: effects of ACE inhibition. Diabetes 47: 414-422

8. Nakamura T, Takahashi T, Fukui M et al. (1995) Enalapril attenuates increased gene expression of extracellular matrix components in diabetic rats. Am Soc Nephrol 5: 1492-1497

9. Bader R, Bader H, Grund KE, Mackensen-Haen S, Christ H, Bohle A (1980) Structure and function of the kidney in diabetic glomerulosclerosis. Correlations between morphological and functional parameters. Pathol Res Pract 167: 204-216

10. Lane PH, Steffes MW, Fioretto P, Mauer SM (1993) Renal interstitial expansion in insulin-dependent diabetes mellitus. Kidney Int 43: 661-667

11. Miner JH (1999) Renal basement membrane components. Kidney Int 56: 2016-2024

12. Jerums G, Allen TJ, Cooper ME (1989) Triphasic changes in selectivity with increasing proteinuria in type 1 and type 2 diabetes. Diabet Med 6: 772-779

13. Gilbert RE, Wilkinson-Berka JL, Johnson DW et al. (1998) Renal expression of transforming growth factor-beta inducible gene-h3 (beta ig-h3) in normal and diabetic rats. Kidney Int 54: 1052-1062

14. Chomczynski P, Sacchi N (1987) Single-step method of RNA isolation by acid guanidinium thiocyanate-phenolchloroform extraction. Anal Biochem 162: 156-159

15. Martorana AM, Zheng G, Springall F, Iland HJ, O'Grady RL, Lyons JG (1999) Absolute quantitation of specific mRNAs in cell and tissue samples by comparative PCR. Biotechniques 27: 136-144

16. McLennan SV, Yue DK, Turtle JR (1998) Effect of glucose on matrix metalloproteinase activity in mesangial cells. Nephron 79: 293-298

17. Zucker S, Hymowitz M, Conner C et al. (1999) Measurement of matrix metalloproteinases and tissue inhibitors of metalloproteinases in blood and tissues. Clinical and experimental applications. Anna NY Acad Sci 878: 212-227

18. Lehr HA, van der Loos CM, Teeling P, Gown AM (1999) Complete chromogen separation and analysis in double immunohistochemical stains using Photoshop-based image analysis. J Histochem Cytochem 47: 119-126

19. Lehr HA, Mankoff DA, Corwin D, Santeusanio G, Gown AM (1997) Application of photoshop-based image analysis to quantification of hormone receptor expression in breast cancer. Histochem and Cytochem 45: 1559-1565

20. Gilbert RE, Rumble JR, Cao Z et al. (2000) Endothelin receptor antagonism ameliorates mast cell infiltration, vascular hypertrophy, and epidermal growth factor expression in experimental diabetes. Circ Res 86: 158-165

21. Gilbert RE, Cooper ME (1999) The tubulointerstitium in progressive diabetic kidney disease: more than an aftermath of glomerular injury? Kidney Int 56: 1627-1637

22. Massova I, Kotra LP, Fridman R, Mobashery S (1998) Matrix metalloproteinases: structures, evolution, and diversification. FASEB 12: 1075-1095

23. Adler SG, Feld S, Striker L et al. (2000) Glomerular type IV collagen in patients with diabetic nephropathy with and without additional glomerular disease. Kidney Int 57: 2084-2092

24. Border WA, Noble NA (1997) TGF-beta in kidney fibrosis: a target for gene therapy. Kidney Int 51: 1388-1396
25. Overall CM, Wrana JL, Sodek J (1991) Transcriptional and post-transcriptional regulation of $72-\mathrm{kDa}$ gelatinase/Type IV collagenase by transforming growth factor beta1 in human fibroblasts. J Biol Chem 266: 14064-14071

26. Suzuki D (1998) Metalloproteinases in the pathogenesis of diabetic nephropathy. Nephron 80: 125-133

27. Border WA, Yamamoto T, Noble NA (1996) Transforming growth factor beta in diabetic nephropathy. Diabetes Metab Rev 12: 309-339

28. Bruijn JA, Roos A, de Geus B, de Heer E (1994) Transforming growth factor-beta and the glomerular extracellular matrix in renal pathology. J Lab Clin Med 123: 34-47

29. Nakamura T, Ebihara I, Fukui M et al. (1995) Effects of enalapril treatment on gene expression of smooth muscle myosin heavy chain isoforms in glomeruli of diabetic rats. Ren Physiol Biochem 18: 183-190

30. Suzuki J, Isobe M, Kawauchi M, Endoh M, Amano J, Takamoto S (2000) Altered expression of matrix metalloproteinases and tissue inhibitors of metalloproteinases in acutely rejected myocardium and coronary arteriosclerosis in cardiac allografts of nonhuman primates. Transplt Int 13: 106-113

31. Kasiske BL, Kalil RS, Ma JZ, Liao M, Keane WF (1993) Effect of antihypertensive therapy on the kidney in patients with diabetes: a meta-regression analysis. Ann Intern Med 118: 129-138

32. Laffel LM, McGill JB, Gans DJ (1995) The beneficial effect of angiotensin-converting enzyme inhibition with captopril on diabetic nephropathy in normotensive IDDM patients with microalbuminuria. North American Microalbuminuria Study Group. Am Med 99: 497-504

33. Lewis EJ, Hunsicker LG, Bain RP, Rohde RD (1993) The effect of angiotensin-converting-enzyme inhibition on diabetic nephropathy. The Collaborative Study Group. N Engl Med 329: 1456-1462

34. Zatz R, Dunn BR, Meyer TW, Anderson S, Rennke HG, Brenner BM (1986) Prevention of diabetic glomerulopathy by pharmacological amelioration of glomerular capillary hypertension. J Clin Invest 77: 1925-1930

35. Cooper ME, Allen TJ, Macmillan PA, Clarke BE, Jerums G, Doyle AE (1989) Enalapril retards glomerular basement membrane thickening and albuminuria in the diabetic rat. Diabetologia 32: 326-328

36. Kagami S, Border WA, Miller DE, Noble NA (1994) Angiotensin II stimulates extracellular matrix protein synthesis through induction of transforming growth factor-beta expression in rat glomerular mesangial cells. J Clin Invest 93: 2431-2437

37. Wolf G, Neilson EG (1993) Angiotensin II as a renal growth factor. Am Soc Nephrol 3: 1531-1540

38. Ruiz-Ortega M, Egido J (1997) Angiotensin II modulates cell growth-related events and synthesis of matrix proteins in renal interstitial fibroblasts. Kidney Int 52: 1497-1510

39. Allen TJ, Cao Z, Youssef S, Hulthen UL, Cooper ME (1997) Role of angiotensin II and bradykinin in experimental diabetic nephropathy. Functional and structural studies. Diabetes 46: 1612-1618

40. Cordonnier DJ, Pinel N, Barro C et al. (1999) Expansion of cortical interstitium is limited by converting enzyme inhibition in type 2 diabetic patients with glomerulosclerosis. The Diabiopsies Group. J Am Soc Nephrol 10: 1253-1263

41. Singh R, Alavi N, Singh AK, Leehey DJ (1999) Role of angiotensin II in glucose-induced inhibition of mesangial matrix degradation. Diabetes 48: 2066-2073 